\title{
Hành trình tới sự hoàn mỹ
}

\author{
Bạch Ngọc Chiến \\ Vương Quân Hoàng \\ Tạp chí Kinh tế và Dự báo (ISSN: 0866-7120) \\ Vol. 48, Số 21 (Serial 605) \\ Tháng 10-2015
}

Bạch Ngọc Chiến \& Vương Quân Hoàng (2015). Hành trình tới sự hoàn mỹ. Kinh tế và Dự báo, 48(21/605), tr. 27-29. 


\title{
Hành trình tới sự hoàn mỹ
}

\author{
BACH NGOQC CHIẾN*
}

VƯỞNG QUÂN HOÀNG**

\begin{abstract}
Số phận của nền văn hóa khoa học - công nghệ phụ thuộc rất lớn vào "sự thức tỉnh" của giới tinh hoa kinh tế - chính trị - nghệ thuật về vai trò quan trọng của nó trong việc trợ giúp phát triển kinh tế, gia tăng sức cạnh tranh, "nâng cấp" trình độ lực lượng lao động và quan trọng hơn cả là củng cố hệ “DNA xã hội". Muốn vậy, việc nhận biết và hiểu rõ những cột mốc lớn của sự phân kỳ lịch sử, trong đó tư duy khoa học - công nghệ chính là một nhân tố cốt yếu tạo tiền đề cho những bước nhảy vọt của nhân loại là rất cần thiết.
\end{abstract}

\section{VÉN MÀN ĐÊM ĐEN}

Sự phân kỳ đầu tiên gieo mầm cho ý thức khoa học - kỹ thuật nhân loại là việc bứt khỏi sự lệ thuộc hoàn toàn vào tự nhiên để đáp ứng các nhu cầu căn bản nhất cho sự tồn tại: nhu cầu thể chất sinh lý, mức nền móng của tháp nhu cầu Maslow (Abraham H. Maslow, 1943).

Một cách tự nhiên, "nhu cầu" đã mang ý nghĩa đặc biệt quan trong đối với việc ra đời các phát kiến và sáng chế kỹ thuật (Necessity is the mother of invention). Thiếu thốn tài nguyên, thức ăn, đồ dùng gây ra phản ứng với tác nhân gây stress và khiến cho các cộng đồng ban đầu suy nghĩ tìm cách bù đắp sự thiếu thốn, hoặc thay thế đồ dùng. Đó cũng là xuất phát điểm của "thuyết nhu cầu".

Những phát kiến và sáng chế sơ khai ấy được cải thiện và phong phú dần theo thời gian. Nghiên cứu về những nền văn minh đầu tiên của loài người, các bằng chứng khoa học mới nhất đã chỉ ra rõ rệt sự tích tụ kiến thức và kỹ năng thông qua những sáng tạo công nghệ đáng kính nể. Trong nghiên cứu xuất bản tháng 9/2015, Lodoloa và Ben-Avrahamb công bố phát hiện cột đá kích thước cực lớn, cao tới 12 mét, được chế tạo ra từ đá nguyên khối, nặng khoảng 15 tấn được dựng lên trên vùng nối Tunisia với Sicily, cùng với nhiều chi tiết kỹ thuật gây thắc mắc về công năng cũng như đặt dấu hỏi về khả năng công nghệ của cư dân cổ đại. Vùng đất này bị chìm sâu vào lòng đại dương, khoảng 9350 năm trước, mang theo những công trình chứa đầy bí ẩn về năng lực kỹ thuật và đầu óc sáng tạo của các nền văn hóa tiền sử (Emanuele Lodoloa and Zvi Ben-Avrahamb, 2015).

Quá trình phân kỳ đầu tiên đã diễn ra trong hàng triệu năm. Con người với kỹ năng và đầu óc kỹ thuật, ước muốn hiểu biết và niềm khao khát có sức sống mạnh mẽ đã trở thành chúa tể của muôn loài.

\section{HIẾU QUẢ CỦA HỌC TẬP XÃ HộI}

Sự ra đời của xã hội loài người có tổ chức đã thúc đẩy giai đoạn phân kỳ tiếp theo đối với nền tảng tri thức khoa học - công nghệ, ở một mức độ ý thức cao hơn hẳn. Thực chất, về lâu dài, sự hình thành hệ thống văn hóa sẽ quyết định xu hướng phát triển khoa học công nghệ. Trong định nghĩa văn hóa, ý niệm về hệ thống hành vi có thể truyền dẫn theo phương thức xã hội là đặc biệt quan trọng trong mục tiêu so sánh các xã hội. Phương thức truyền dẫn như thế được gọi là quá trình học tập xã hội (Carel P. van Schaik et al, 2013).

Học tập xã hội cho phép các cá nhân xây dựng hệ hành vi phù hợp với điều kiện sinh thái. Có rất nhiều bằng chứng chỉ ra sáng chế và sử dụng công cụ là kết quả của sự học tập và truyền dạy có tính xã hội từ thuở sơ khai, khi chưa có ngôn ngữ. Đồng thời, với hệ "DNA xã hội" điều khiển hành vi của các thành viên, tốc độ tiến bộ nhận thức của các cộng đồng, cùng các phương tiện như ngôn ngữ... cũng ảnh hướng tới tốc độ thay đổi của nền tảng hiểu biết kỹ thuật.

Sư tiến bộ nhận thức của xã hội có tổ chức tinh vi và phân công lao động rõ rệt đã thúc đẩy sự phân kỳ của tri thức con người tiếp tục lên bậc cao hơn nữa và trở thành đặc trưng cũng như các dấu mốc phát kiến kỹ thuật của nền văn minh, như: thuyền buồm ở Ai Cập, bánh xe ở Trung Quốc, trống đồng ở Việt Nam, hay các công trình xây dựng đòi hỏi các tính toán kỹ thuật và khả năng điều phối - tổ chức hiệu quả. 
HìNH 1: TĂNG TRƯởNG GDP BìNH QUÂN ĐẦU NGƯỜI CỦA VIỆT NAM GIAI ĐOẠN 1994-2014

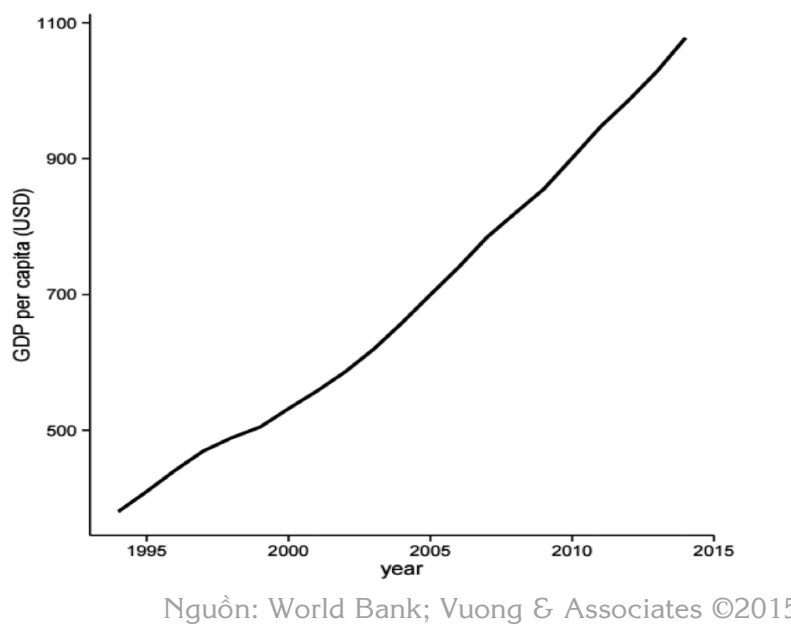

Giai đoạn phân kỳ trí lực này thực chất nâng tầm của con người lên so với chính mình, chứng minh khả năng tự đáp ứng nhu cầu nhờ đầu óc tư duy và sự tìm tòi, khám phá. Xã hội loài người thời kỳ này cũng tự tạo ra các tiền đề cho việc ra đời các ngành khoa học thực sự, như cách người Hy Lạp tiến hành với các bộ môn vật lý, toán học, thiên văn, y học... dần thoát ly khỏi các nhu cầu trước mắt, chứng tỏ viê̂n kiến, trí tưởng tượng và cả khao khát giàu tính mỹ học.

\section{KỶ NGUYÊN CÁCH MẠNG KHOA HỌC-CÔNG NGHẸ}

Đối với Việt Nam, quá trình chuyển dịch từ mô hình kinh tế tập trung bao cấp sang kinh tế thị trường đã mở ra một trang sử mới. Sự tham gia của khoa học-kỹ thuật trong công cuộc công nghiệp hóa, hiện đại hóa đất nước đã mang lại cho Việt Nam gần 30 năm đổi mới, nhất là 20 năm gần đây sinh lực kinh tế vững hơn trong thời kỳ hội nhập quốc tế.

Hình 1 cung cấp cái nhìn trực quan về sự tăng trưởng và phát triển của kinh tế Việt Nam giai đoạn 1994-2014 thông qua số liệu thực chửng về GDP bình quân đầu người. Năm 1994, GDP bình quân đầu người của Việt Nam chỉ ở mức 380 USD. Đến năm 2014, con số này đã tăng lên gần 300\%, đạt 1.078 USD (theo giá so sánh 1994). Đường biểu thị GDP bình quân đầu người trong biểu đồ có độ dốc khá lớn, đặc biệt ở giai đoạn 20052014, cho thấy kinh tế Việt Nam đã tích lũy sinh lực tương đối nhanh trong khoảng 10 năm trở lại đây. Có thể xem đây là kết quả của quá trình đổi mới với nỗ lực ứng dụng khoa học - công nghiệp trong tổ chức sản xuất, vận hành. Cùng với đó là sự bùng nổ của công nghệ, thông tin đã thay đổi phương thức trao đổi thông tin, tổ chức, quản lý... cả ở mức độ vi mô và vĩ mô.

Câu hỏi đặt ra là: từ đâu và bằng cách nào khoa học, kỹ thuật hiện đại đã đến và tạo ra những đột phá vĩ đại đó? Hay nói khác đi, cần nhìn lại quá trình bùng nổ, lan tỏa và vai trò của khoa học - công nghệ trong việc liên tục tái sắp xếp trật tự xã hội.
Nhìn lại tiến trình lịch sử, thế kỷ XVIII đã chứng kiến sự thăng hoa cao độ của cuộc cách mạng khoa học - kỹ thuật nhân loại chính thức bắt đầu, mặc dù các dấu vết của sư khai nở đã xuất hiện từ thế kỷ XV. Giai đoạn 1760-1850 là giai đoạn nước Anh trở thành nơi trình diễn của những "ảo thuật gia công nghệ". Thành tựu tiếp nối thành tựu, nhờ trí tuệ và sức lao động, được tiếp sức bởi hệ thống thị trường và thể chế xã hội hiện đại. Tiếp đến là cơ khí hóa thổi sức sống vào những ngành nghề đã có lâu đời, nhờ năng suất lao động vượt trội và tiết kiệm sức lực, thời gian của nhân công.

Nước Anh đạt được những thành tựu mang tính bước ngoắt và tạo ra một cuộc đảo lộn về vị thế kinh tế trên toàn cầu. Khi nước Anh chuẩn bị bước vào tâm điểm cách mạng công nghiệp, năm 1750, thì Trung Quốc đang chiếm 33\% sản lượng kinh tế toàn cầu, một cường quốc thực sự. Ân Độ cũng là cường quốc, chiếm $25 \%$. Sản lượng đầu người ở hai cường quốc này thấp hơn trung bình ở các nước giàu của Tây Âu vào lúc đó, nhưng mức chênh lệch không nhiều.

Kết quả của sự tích lũy sinh lực kinh tế do 160 năm tiến bộ khoa học - công nghệ mang lại, đó là năm 1913, Anh, Mỹ và Tây Âu chiếm $3 / 4$ sản lượng kinh tế toàn cầu, Trung Quốc chỉ còn $4 \%$ và Ấn Độ $1 \%$. Đó mới chỉ nói về tỷ lệ, nói về trị số tuyệt đối thì chênh lệch còn ấn tượng hơn nhiều.

Song, sự lý thú của khoa học - công nghệ và cuộc đổi ngôi tiếp theo đã xảy ra. Khi nước Mỹ và Đức thực sự bùng nổ với làn sóng công nghiệp hóa trong giai đoạn 1880-1938, từ vị thế khách hàng nhập khẩu các phát minh và công nghệ từ Anh, Mỹ trở thành lãnh đạo kinh tế với sản lượng 33\% toàn cầu, và Đức $24 \%$. Tỷ trọng của cựu lãnh đạo thế giới - nước Anh - giảm xuống còn 13\% (Robert C. Allen, 2011)

Những con số này được nhắc lại nhằm phục vụ một quan điểm được gọi là sự phân kỳ lớn thứ 3 của hệ tri thức nhân loại: sự đảo lộn vị trí, đổi ngôi và đeo bám nhau quyết liệt trong một thời gian không dài (nếu so với lịch sử 11.700 năm tồn tại của nền văn minh xã hội). Không nghi ngờ gì nữa, bản chất của những thay đổi lởn này là sự bồi đắp nền tảng tri thức khoa học - công nghệ với tốc độ và hướng khác nhau, dẫn đến mức chênh lệch rất lớn giữa các xã hội khác nhau. 


\section{VƯớN TỚI TÍNH HOÀN MỸ CỦA Sự SÔNG}

Trong cuốn Faraday's Diary of Experimental Investigation (Tập 7) ghi chép thí nghiệm cuối cùng của Michael Faraday được đánh số 16.041, vào năm 1860, đây là con số khổng lồ ghi lại số lượng những suy nghĩ khoa học đã thành hình. Với con số 16.041 thí nghiệm, Faraday đã miệt mài 42 năm chuyên cần, bền chí, vượt lên trên thân phận cậu bé học dở lớp 3 , đã từng đóng sách thuê để kiếm sống phụ giúp gia đình, rồi trở thành một trong những nhà khoa học vĩ đại nhất mọi thời đại.

Ở đầu thế kỷ XXं, do cạnh tranh quá lớn và đòi hỏi ngày một khắt khe của thế giới hàn lâm, sự phấn đấu của các nhà khoa học phải gọi là nỗ lực khắc kỷ để có được chỗ đứng xứng đáng - theo cách mà cây bút biên tập PNAS Verma gọi là "thảm cảnh" cạnh tranh sinh tồn giữa những kẻ mạnh nhất. Thế nhưng, số lượng người lựa chọn chấp nhận sự khắt khe này vẫn tăng lên, bất chấp thực tế nghiệt ngã về đòi hỏi lý lịch khoa học thay đổi như "bắn mục tiêu di động"!

Câu chuyện về Faraday ở thế kỷ XVIII và các nhà khoa học thế kỷ XXI đã cho thấy nỗ lực phi thường của những người ngày đêm lao động sáng tạo. Chỉ có thể giải thích rằng, thực sự hệ giá trị và văn hóa khoa học đã trở thành nền tảng xã hội hiện đại và ước mơ tự hoàn thiện của xã hội càng phát triển càng mạnh mẽ và thôi thúc hơn. Ước mơ đó rất khác so với mong muốn đạt mức lợi ích vật chất quy đổi về giá trị tiền tệ. Nó nằm ở đỉnh của tháp nhu cầu Maslow.

Tính hoàn mỹ khoa học vươn tới dĩ nhiên cần sự đồng hành của phát kiến công nghệ như đã bàn ở phần trước. Nhưng, ở nền tảng đoạn phân kỳ vĩ đại đang bàn, khoa học được xây dựng trên cả một hệ thống kiến thức đúc rút từ rất lâu trước đó. Nói như Appleby thì: Công nghệ gặp khoa học, rồi làm nên một cuộc hôn phối vĩnh cửu! (Joyce Oldham Appleby, 2010).

Con người có nhiều khát vọng và hành trình vươn tới đỉnh cao luôn có bóng dáng của những giá trị mỹ học. Ngày nay chúng ta đã được chứng kiến các nỗ lực khoa học giá trị, thậm chí đến mức khó tưởng, nhằm tìm tới tận cùng những câu hỏi về sự sống, biên giới cái đẹp của trí tưởng tượng nhân loại. Và sự tiến bộ của khoa học - công nghệ, sự sung túc của đời sống vật chất và tinh thần của con người được hy vọng sẽ bồi đắp cho lòng nhân đạo và vị tha bất diệt.

Nếu không phải thế thì Erwin Schrodinger nhọc công với câu hỏi nguồn gốc sự sống để làm gì? (Erwin Schrodinger, 1946), hoặc do đâu mà Stephen Hawking rất đỗi lo lắng về tương lai chạy đua vũ trang bằng đội quân robot có trí tuề nhân tạo đủ để tiêu diệt con người? Hay tại sao chỉ chơi một khúc Chopin cũng khiến Oscar Wilde "thấy mình như khóc vì ăn năn những lỗi lầm của kẻ khác và đau xót cho những tấn bi kịch không xảy ra với mình"?

Xuyên suốt bốn mốc phân kỳ của lịch sử, hệ văn hóa khoa học - công nghệ đã nổi lên như một ngọn hải đăng dẫn lối nhân loại đi từ đêm đen tiền sử đến đỉnh cao rạng ngời của khát khao tự hoàn thiện đầy giá trị mỹ học. Quay trở lại câu chuyện hoa khoai tây ở châu Âu, có thể thấy, thời nào và ở đâu, hạt mầm của văn hóa khoa học - công nghệ cũng sẽ luôn cần đến bàn tay của giới tinh hoa chính trị - kinh tế - nghệ thuật gieo xuống. Đặc biệt, với quốc gia đang phát triển như Việt Nam, càng cần hơn những hạt mầm và những bàn tay đó.

\section{TÀI LIỆU THAM KHẢO}

1. Abraham H. Maslow (1943). A theory of human motivation, Psychological Review, 50(4), 370-396

2. Carel P. van Schaik, Marc Ancrenaz, Gwendolyn Borgen, Birute Galdikas, Cheryl D. Knott, Ian Singleton, Akira Suzuki, Sri Suci Utami, and Michelle Merrill (2003). Orangutan cultures and the evolution of material culture, Science, 229(5603), 102-105, 2003. DOI:10.1126/science.1078004

3. Charles C. Mann (2011). How the potato changed the world, Smithsonian Magazine

4. Emanuele Lodoloa and Zvi Ben-Avrahamb (2015). A submerged monolith in the Sicilian Channel (central Mediterranean sea): evidence for Mesolithic human activity, Journal of Archaeological Science: Reports, 3, 398-407, 2015, DOI:10.1016/j.jasrep.2015.07.003

5. Erwin Schrodinger (1946). What is life? The physical aspect of the living cell, Cambridge University Press, Cambridge, UK

6. Michael Faraday (2008). Faraday's diary of experimental investigation, Vol. 7. HR Direct, Riverton, UT, 2008

7. Robert C. Allen (2011). Global economic history: a very short introduction, Oxford University Press, New York, NY, 2011, 42-5

8. Joyce Oldham Appleby (2010). The relentless revolution: a history of capitalism, W.W. Norton, New York, NY 